\title{
Flavonoids Protect Against T-2 Mycotoxins both in vitro and in vivo
}

\author{
By R. J. F. MARKHAM, $†$ N. P. ERHARDT, V. L. DININNO, D. PENMAN \\ AND A. R. BHATTI* \\ Preventive Medicine Section, Defence Research Establishment Suffield, Ralston, Alberta, \\ Canada TOJ $2 \mathrm{NO}$
}

(Received 28 October 1986; revised 9 February 1987)

Quercetin was able to reduce the cytotoxic effect of T-2 mycotoxin on cultured murine thymocytes. When given to mice immediately before challenge with $\mathrm{T}-2$ mycotoxins, quercetin significantly reduced mortality.

\section{INTRODUCTION}

Trichothecene mycotoxins are a chemically related group of secondary metabolites of Fusarium and some other fungi which are toxic in both man and animals. Mycotoxins have been implicated as the cause of inadvertent food intoxication following fungal contamination of foodstuffs (Greenway \& Puls, 1976; Hsu et al., 1972; Ueno et al., 1972) and recent studies have suggested their use as biological warfare agents (Mirocha et al., 1983; Rosen \& Rosen, 1982).

While some compounds are beneficial in treating mycotoxin poisoning, there is no widely accepted treatment. Anecdotal reports from South East Asia suggest that extracts of plants rich in bioflavonoids can be successful in the treatment of mycotoxicosis. Bioflavonoids are common constituents of many plants and are widely distributed in nature. They have a variety of effects on mammalian tissue and organ systems (Willaman, 1955). Quercetin (3,3',4',5,7-pentahydroxyflavone), one such bioflavonoid compound, has received considerable attention for its inflammatory effects and influence on other organ systems (Middleton et al., 1985).

Previous work from this laboratory has shown that mycotoxins, in particular T-2 mycotoxin, have potent cytotoxic capabilities in vitro, expressed as a loss of viability of thymocytes and other leucocytes (DiNinno et al., 1985). Here we describe the effect of quercetin on this in vitro cytotoxicity and on the lethal effects of T-2 mycotoxin on mice.

\section{METHODS}

Cell cultures. Isolated thymus cells were prepared as described by Shiigi et al. (1980). Black male C-57 mice 3-6 weeks old, were used in all but one experiment where 24-week-old mice were used. The mice were killed by $\mathrm{CO}_{2}$ inhalation and the thorax was flooded with $70 \%(\mathrm{v} / \mathrm{v})$ ethanol prior to removal of the thymus. For each assay, at least two thymi were collected. After removal, the thymi were placed in a Petri dish containing Joklik's Medium (Flow Laboratories) and minced with scissors and teased apart to dissociate cells. The cell suspension was washed by centrifugation $\left(400 \mathrm{~g}\right.$ for $20 \mathrm{~min}$ at $\left.25^{\circ} \mathrm{C}\right)$ and the pellet was resuspended in the same medium to give a concentration of $2 \times 10^{7}$ cells $\mathrm{ml}^{-1}$

Mycotoxins. T-2 mycotoxin (Sigma) was dissolved in dimethylsulphoxide (DMSO) to give a stock solution of 20 $\mathrm{mg} \mathrm{ml}^{-1}$. Further dilution in DMSO allowed addition of specified amounts of mycotoxin to $0.5 \mathrm{ml}$ cell suspension $\left(1 \times 10^{7}\right.$ cells). The amount of DMSO added did not exceed $25 \mu \mathrm{l}$ and controls, containing cells and DMSO alone, were tested to detect any inherent cytotoxicity of DMSO.

Cytotoxicity assay. Cytotoxicity was assessed by determining the viability of thymocytes using dye exclusion with $0.2 \%$ eosin (Shiigi et al., 1980). At specified times after addition of T-2 mycotoxin to the cells, a portion of the

† Present address: Department of Pathology and Microbiology, Faculty of Veterinary Medicine, University of Prince Edward Island, Charlottetown, PEI, Canada C1A 4P3.

Abbreviation: DMSO, dimethylsulphoxide.

0001-3794 (C) 1987 Crown copyright 


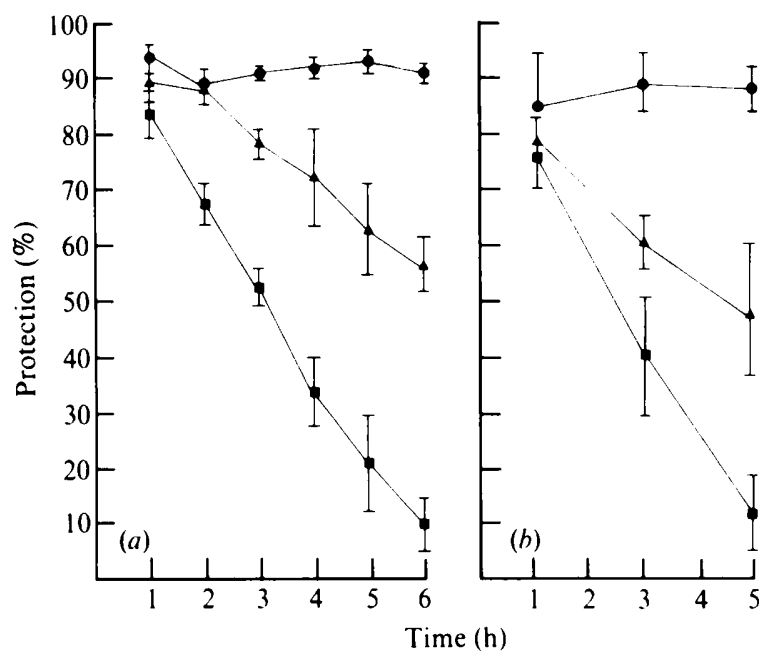

Fig. 1. Protective effect of quercetin on cytotoxicity of T-2 mycotoxin on murine thymocytes. Control cells incubated with DMSO. C, Cells incubated with $400 \mu \mathrm{g} \mathrm{T}-2$ mycotoxin $\mathrm{ml}^{-1}(a)$, or $200 \mu \mathrm{g}$ $\mathrm{T}-2$ mycotoxin $\mathrm{ml}^{-1}(b) . \Delta$, Cells incubated with $400 \mu \mathrm{g} \mathrm{T}-2$ mycotoxin $\mathrm{ml}^{-1}$ plus $10 \mu \mathrm{g}^{2}$ quercetin $\mathrm{ml}^{-1}$ (a) or $200 \mu \mathrm{g} \mathrm{T}-2$ mycotoxin $\mathrm{ml}^{-1}$ plus $10 \mu \mathrm{g}$ quercetin $\mathrm{ml}^{-1}(b)$. Data represent means $\pm \mathrm{SD}$ of at least four separate experiments. $P \leqslant 0.02$ at $2 \mathrm{~h}(a)$ or $3 \mathrm{~h}(b)$ or more as determined by Student's $t$-test.

mixture was removed and mixed with an equal volume of eosin solution. Cells were examined microscopically in a Neubauer haemocytometer and the viability of at least 200 cells was determined.

Quercetin (Sigma) was dissolved in DMSO and added to the T-2 mycotoxin/thymocyte mixture at specified times. Controls were included to determine if quercetin and additional DMSO had a cytotoxic effect on the thymocytes. In other experiments, quercetin was added before or after introduction of T-2 mycotoxin into the thymocyte culture.

In vivo protection. Mice were challenged by intraperitoneal injection of $4 \mathrm{mg} \mathrm{T}-2$ mycotoxin (dissolved in DMSO) $\mathrm{kg}^{-1}$. This dose represented approximately $1 \mathrm{MLD}$. Mice receiving quercetin were given the drug immediately before (within $15 \mathrm{~min}$ ) injection of T-2 mycotoxin. Quercetin was prepared for injection by entrapment in phospholipid vesicles (liposomes). Quercetin was dissolved in absolute ethanol and DMSO (10:1, $\mathrm{v} / \mathrm{v}$ ) to give a solution of $40 \mathrm{mg} \mathrm{m}^{-1}$ and $450 \mu \mathrm{l}$ was placed in a test tube. An equal volume of egg-yolk phosphatidylcholine (Sigma) (100 mg ml-1 in chloroform/ethanol) was added and the mixture was dried under $\mathrm{N}_{2}$ and subsequently in a vacuum desiccator. Saline $(2 \mathrm{ml})$ was added to the dried film and the test tube was shaken vigorously to form multilamellar vesicles (MLV). The liposome suspension was diluted with saline to a total volume of $20 \mathrm{ml}$. This was given to mice at concentrations of 10-20 or 20-30 mg quercetin per ml of liposome suspension.

\section{RESULTS AND DISCUSSION}

In Fig. 1 it is apparent that quercetin offered significant protection against cytotoxicity. At the concentrations of T-2 mycotoxin tested, quercetin reduced the cytotoxic effects on thymocytes by approximately $40 \%$. This protection was greatest when the drug was added before or at the same time as addition of T-2 mycotoxin to the thymocyte cultures (Fig. 2). Delaying the addition of quercetin by $2 \mathrm{~h}$ significantly reduced its protective effect. When quercetin was given to mice just before lethal challenge with T-2 mycotoxin, significant protection was obtained at both 24 and $48 \mathrm{~h}$ after challenge (Table 1). Apparent differences between quercetin treatment doses were not significant upon chi-square analysis. Quercetin at lower doses, or liposomes themselves, had no protective effect (data not shown).

It has been suggested that inhibition of protein synthesis and, to a lesser degree, inhibition of DNA and RNA synthesis is responsible for the observed toxic effects of T-2 mycotoxin (Oldham et al., 1980; Ueno et al., 1973). More recent studies, however, have focused on alterations in cell membranes as mechanisms of cytotoxicity and pathological consequences 


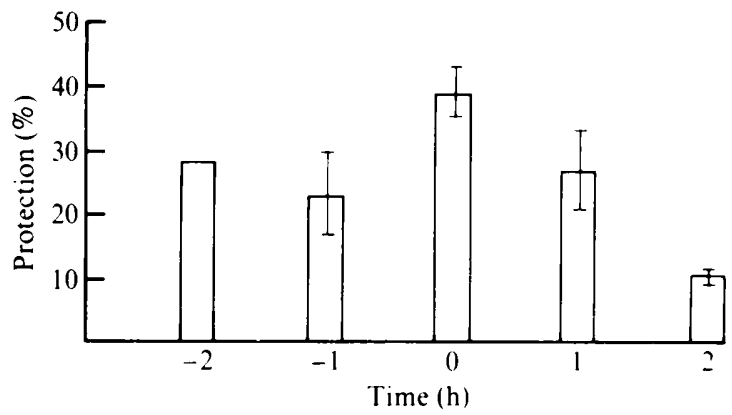

Fig. 2. Effect of the time of addition of quercetin on the protection from cytotoxicity of T-2 mycotoxin on murine thymocytes. Cells were mixed with $200 \mu \mathrm{g} \mathrm{T}-2$ mycotoxin $\mathrm{ml}^{-1}$ at $0 \mathrm{~h}$ and $10 \mu \mathrm{g}$ quercetin $\mathrm{ml}^{-1}$ was added at the times indicated. Cytotoxicity assays were done $5 \mathrm{~h}$ after the addition of T-2 mycotoxin. Except for $-2 \mathrm{~h}$, which was a single trial, the data represent means \pm SD of at least three separate experiments.

\section{Table 1. Effect of quercetin on T-2-mycotoxin-induced mortality in mice}

Mortality is expressed as (no. mice dead)/(no. mice challenged), and as a percentage in parenthesis. Both quercetin groups showed significant reduction in mortality $(P<0.002)$ when data was subjected to chi-square analysis.

$\begin{array}{ccc}\begin{array}{c}\text { Dose of } \\ \text { quercetin } \\ \left(\mathrm{mg} \mathrm{kg}^{-1}\right)\end{array} & \overbrace{24 \mathrm{~h}} & 48 \mathrm{~h} \\ 0 & 48 / 72(67) & 64 / 72(89) \\ 10-20 & 13 / 53(25) & 25 / 53(47) \\ 20-30 & 11 / 36(31) & 21 / 36(58)\end{array}$

seen in mycotoxin poisoning (Gyongyossy-Issa et al., 1985; Rottem et al., 1984; Scappert \& Khachatourians, 1984; Segal et al., 1983).

Quercetin is among a large number of flavonoid compounds commonly found in a variety of fruits and vegetables (Kühnau, 1976). These flavonoid compounds have manifold biological properties and have been used as diuretics, heart stimulants, antiviral agents, antitumour agents and antihistaminics (Willaman, 1955). Quercetin itself has anti-inflammatory properties, inhibits NADPH oxidase in neutrophils and will decrease spontaneous lipid peroxidation following glutathione depletion in rats (Beretz et al., 1982; Tauber, 1984; Younes \& Sigers, 1981). While there is no clear indication of how quercetin protects against T-2 toxicosis, evidence implicating participation of cell membranes in the effects of T-2 mycotoxin suggests that activities relating to inhibition of lipid peroxidation or stabilization of cellular enzyme activation may be involved. As has been observed for related flavonoid compounds, quercetin may also activate degrading enzymes in the liver (Newberne, 1975). However, because of the ability of quercetin to protect in vitro, the former mechanism must also be relevant.

Other attempts to reduce the effect of T-2 mycotoxin poisoning have included the administration of zeolite or bentonite to reduce intestinal absorption, and the administration of inducers of microsomal enzymes or agents which increase hepatic glutathione levels (Carson \& Smith, 1983; Fricke, 1983; Fricke et al., 1984). It may be that quercetin or other flavonoid compounds share some of these activities and may be viewed as possible therapeutic agents.

\section{REFERENCES}

Beretz, A., Cazenave, J. P. \& Anton, R. (1982). Inhibition of aggregation and secretion of human platelets by quercetin and other flavonoids. Structure-activity relationships. Agents and Actions 12, 382-387.
Carson, M. S. \& SMITh, J. K. (1983). Role of bentonite in prevention of $\mathrm{T}-2$ toxicosis in rats. Journal of Animal Science 57, 1498-1506.

Dininno, V. L., Penman, D., Bhatti, A. R., ERHARDT, N. P. \& LOCKWOOD, P. A. (1985). In vitro 
toxicity of T-2 mycotoxin in mouse lymphoid cells. Journal of General Microbiology 131, 1833-1835.

Fricke, R. F. (1983). Decreased toxicity of T-2 mycotoxin in mice pretreated with microsomal enzyme inducers. Federation Proceedings 42, 626.

Fricke, R. F., Beauchamp, B. \& KeEling, L. (1984). Effect of glutathione prodrugs on lethality of T-2 mycotoxin in mice. Federation Proceedings 44, 656

Greenway, J. A. \& Puls, R. (1976). Fusariotoxicosis from barley in British Columbia. I. Natural occurrence and diagnosis. Canadian Journal of Comparative Medicine 40, 12-15.

Gyongyossy-Issa, M. I. C., Khanna, V. \& KhachaTOURIANS, G. G. (1985). Characterization of hemolysis induced by T-2 toxin. Biochimica et biophysica acta 838, 252-256.

Hsu, I. C., Smalley, E. B., Strong, F. M. \& Ribelin, W. E. (1972). Identification of T-2 toxin in moldy corn associated with lethal toxicosis in dairy cattle. Applied Microbiology 24, 684-690.

KüHNAU, J. (1976). The flavonoids. A class of semiessential food components: their role in human nutrition. World Review in Nutrition and Dietetics 24, 117-191.

Middleton, E., Drzewoecki, G. \& Krishnarao, D. (1981). Quercetin: an inhibitor of antigen induced human basophil release. Journal of Immunology 127, 546-550.

Mirocha, C. J., Pawlosky, R. A., Chatterjee, K., Watson, S. \& HaYes, W. (1983). Analysis for Fusarium toxins in various samples implicated in biological warfare in Southeast Asia. Journal of the Association of Official Analytical Chemists 66, 14851499.

NeWBerne, P. M. (1975). Influence on pharmacological experiments of chemicals and other factors in diets of laboratory animals. Federation Proceedings 34, 204-218.

Oldham, J. W., Allred, L. E., Milo, G. E., Kindigo, O. \& CAPEN, C. C. (1980). The toxicological evaluation of the mycotoxins T-2 and T-2 tetrol using normal human fibroblasts in vitro. Toxicology and Applied Pharmacology 52, 159-168.

Rosen, R. T. \& Rosen, J. D. (1982). Synthetic material in 'yellow rain': evidence for the use of chemical weapons in Laos. Biomedical Mass Spectrometry 9 , 443-450.

Rottem, S., Yagen, B. \& Katznell, A. (1984). Effect of trichothecenes on growth and intracellular pool size of Mycoplasma gallisepticum. FEBS Letters 175 , 189-192.

Schappert, K. T. \& Khachatourians, G. G. (1984). Influence of the membrane on T-2 toxicity in Saccharomyces spp. Applied and Environmental Microbiology 47, 681-684.

Segal, R., Milo-Goldzweig, I., Joffe, A. Z. \& YAGEN, B. (1983). Trichothecene-induced hemolysis. The hemolytic activity of T-2 toxin. Toxicology and Applied Pharmacology 70, 343-349.

Shitgi, S. M., Henry, C., Chan, E. L., North, J., Gaillily, R., Slomich, M., Miller, K., MarBROOK, J., Park, D. \& GoOD, A. H. (1980). Preparation of mouse cell suspensions. In Selected Methods in Cellular Immunology, pp. 3-27. Edited by B. B. Mishell \& S. M. Shiigi. San Francisco: W. H. Freeman.

TAuber, A. I., FAY, J. R. \& MARlette, M. A. (1984). Flavonoid inhibition of the human neutrophil NADPH-oxidase. Biochemical Pharmacology 33, 1367-1369.

Ueno, Y., Ishil, K., SaxaI, K., Kanaeda, S., Tsunoda, H., Tanaka, T. \& Enomoto, M. (1972). Toxicological approaches to the metabolites of Fusarium. IV. Microbial survey on bean-hulls poisoning of horses with the isolation of toxic trichothecenes neosolaniol and T-2 toxin of Fusarium solani. Japanese Journal of Experimental Medicine 42, 187-203.

Ueno, Y., Nakajima, K., Sakai, K., Ishil, K., Sato, N. \& Shimada, N. (1973). Comparative toxicology of trichothecene mycotoxins: inhibition of protein synthesis in animal cells. Journal of Biochemistry 74, 285-296.

Willaman, J. J. (1955). Some biological effects of the flavonoids. Journal of the American Pharmaceutical Association 44, 404-408.

YounES, M. \& Sigers, C. P. (1981). Inhibitory action of some flavonoids on enhanced spontaneous lipid peroxidation following glutathione depletion. Planta medica 43, 240-244. 